\title{
Preface
}

\section{Sam Willner}

W

e are pleased to present this thematic issue of Hygiea Internationalis dealing with the fight against polio in South America and the Iberian Peninsula and to welcome the guest editor professor Juan Antonio Rodriguez from the University of Salamanca introducing the thematic articles.

Besides the thematic issue we are also pleased to present two separate articles.

Axel Klohn and Philippe Chastonay from Switzerland are presenting a contemporary indigenous testimony on the demographic catastrophe in early colonial Peru, based on an extensive manuscript by Guaman Poma de Ayala discussing possible causes for the extinction of large parts of the native population as a consequence of the colonial policy.

Professor Virginie De Luca Barrusse from Paris examines "the health problems of immigration" as revealed by French hygienists in the interwar period from an approach reflecting how immigrant health "becomes the issue of reflection and of public protest as well as a target for public action."

Finally I will also invite the readers to submit articles dealing with the history of public health to coming issues of Hygiea Internationalis. 
